\title{
PEMBUATAN LIMBAH CANGKANG MELINJO MENJADI BRIKET DI DESA PASIR WARU KECAMATAN MANCAK
}

\author{
Achmad Syarifudin \\ Universitas Banten Jaya, Jl. Syech Nawawi Albantani Serang Banten \\ Email : achmad.buker69@gmail.com
}

\begin{abstract}
The aim of the Community Service Program "Kuliah Kerja Nyata" Skills Training is to improve the skills of the people of Desa Pasirwaru Kec. Mancak. The partners of this activity are the Melinjo emping craftsmen community in the village of Pasirwaru, Kec. Mancak. The problem faced is not knowing the use of melinjo shells to produce products that are useful and have a sale value. The method of implementing this service is through (1) Surveying through observation, interviews, and analysis of village problems and potentials, (2) Training on making briquettes from melinjo shells. The result of this program is to increase the community's knowledge and skills regarding the processing of melinjo shell waste into briquettes, this program is expected to facilitate the community in improving their knowledge and skills in treating existing waste.
\end{abstract}

Keywords: Training, Community Empowerment, Waste Management

\begin{abstract}
ABSTRAK
Tujuan Program Pengabdian Masyarakat Kuliah Kerja Nyata Pelatihan Keterampilan Masyarakat Desa adalah untuk meningkatkan keterampilan masyarakat Desa Pasir waru Kec. Mancak. Mitra dari kegiatan ini adalah masyarakat Pengrajin emping Melinjo di desa Pasir waru, Kec. Mancak. Permasalahan yang dihadapi yaitu belum mengetahui pemanfaatan cangkang melinjo untuk mengahasilkan produk yang berguna dan memiliki nilai jual. Metode pelaksanaan pengabdian ini yaitu melalui (1) Survey melalui pengamatan, wawancara, dan analisis permasalahan dan potensi desa, (2) Pelatihan pembuatan briket dari cangkang melinjo. Hasil dari program ini adalah bertambahnya pengetahuan dan keterampilan masyarakat mengenai pengolahan limbah cangkang melinjo menjadi briket, Program ini diharapkan dapat memfasilitasi masyarakat dalam meningkatkan pengetahuan dan keterampilan dalam mengolah limbah yang ada.
\end{abstract}

Kata Kunci: Pelatihan, Pemberdayaan Masyarakat, Pengolahan Limbah

\section{PENDAHULUAN}

Kegiatan Kuliah Kerja Mahasiswa (KKM) atau Kuliah Kerja Nyata (KKN) adalah bentuk kegiatan pengabdian masyarakat oleh mahasiswa dan dosen pembimbing lapangan dengan pendekatan lintas keilmuan dan sektoral pada waktu dan daerah tertentu.. Kuliah Kerja Mahasiswa atau Kuliah Kerja Nyata yang dilakukan oleh Universitas Banten Jaya dikabupaten Serang yang berlokasi di kecamatan Mancak dan terletak dilokasi desa pasir waru merupakan KKM (KKN) tematik berbasis Problem Solving untuk memecahkan masalah dengan tema "Teknologi Tepat Guna, Kewirausahaan dan Pengembangan Budaya Banten “ 


\section{Desa Pasir Waru}

Pada mulanya saat desa ini dihuni, Desa ini masih belum mempunyai nama. Berdasarkan sejarah yang tersampaikan secara turun-menurun, bahwa awal mula lahirnya Desa Pasirwaru, Bermula pada zaman dahulu kala ada seorang pria paruh baya bernama Ki Patih Jaya Beliau berasal dari perbukitan yang tidak jauh dari lokasi pohon waru. Beliau sering berkunjung ke pohon waru tersebut dengan menunggangi kudanya. Beliau sangat menyukai dan senang berada di pohon waru tersebut, dan beliaupun merencanakan dengan para tokoh untuk membentuk sebuah Desa yang diberi nama Desa Pasir Waru.

Secara umum keadaan Desa Pasir Waru merupakan daerah dataran tinggi, dengan ketinggian $200 \mathrm{mdpl}$. Desa Pasir Waru mempunyai iklim tropis sehingga mempunyai pengaruh langsung terhadap aktifitas pertanian dan pola tanam di Desa ini. Dan sebagian besar penduduk pasirwaru adalah pertanian dan wirasusaha. Dan secara umum kecamatan Mancak sebebagai daerah sentra melinjo termasuk didalamnya adalah desa pasirwaru sebagai usaha pembuatan emping.

\section{Briket}

Bahan bakar padat yang telah melalui proses pengarangan bahan baku curah kemudian dilakukan pengempaan dengan tambahan perekat untuk memperoleh bentuk dan karakteristik briket yang diinginkan.

Keunggulan briket; murah, mudah dibakar, laju, pembakaran rendah, nilai kalor tinggi, tidak mudah pecah atau hancur selama disimpan, mempunyai bentuk seragam, tahan terhadap kelembaban udara, panas relatif lebih tinggi, nyala bara cukup lama dan tidak berjelaga sehingga peralatan masak tetap bersih, aman (tidak beracun dan tidak meledak), abu briket dapat dimanfaatkan sebagai pupuk, tidak berbau dan tidak berasap, rasa, bau, dan aroma masakan yang dimasak tetap asli

\section{METODE}

Metode yang digunakan selama proses pelatihan diantaranya adalah (1) pembekalan kepada mahasiswa pendamping lapangan yang dilaksanakan di universitas Banten Jaya dengan pemateri Ibu Tauny Akbari, S.Pd., MIL dosen Teknik Lingkungan Universitas Banten Jaya (2) pelaksanaan pelatihan pada masyarakat di desa Pasirwaru yang diawali dengan pemberian materi mengenai pemanfaatan limbah cangkang melinjo dan cara pemanfaatannya, pengenalan nama-nama bahan kimia yang digunakan, (3) Demonstrasi pembuatan briket oleh mahasiswa pendamping, (4) Praktek Pembuatan briket dengan bimbingan Tim KKM Unbaja dan mahasiswa pendamping. 


\section{Alat, Bahan dan diagram alur pembuatan briket dari cangkang melinjo}

\section{ALAT}

Alat utama dalam pengolahan proses briket dari cangkang melinjo yaitu tungku pengarangan, Lumang alu, Saringan, Kompor, Panci, Alat cetak.

\section{BAHAN}

Bahan yang digunakan adalah Cangkang melinjo, Sekam padi, Batok Kelapa, Tepung Kanji, Kayu Bakar, dan tepung

Diagram alur proses pembuatan briket dari cangkang melinjo;

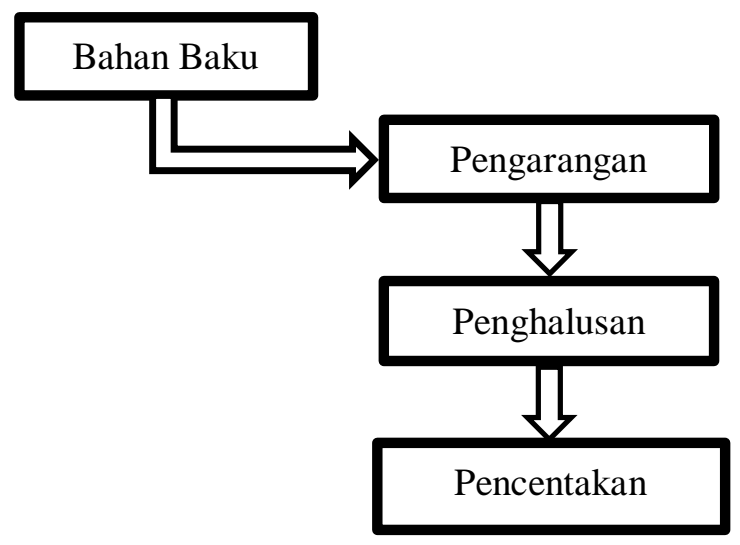

\section{Diagram 1. Proses Pembuatan Briket dari Cangkan Melinjo}

\section{HASIL DAN PEMBAHASAN}

\section{Pembekalan kepada mahasiswa pendamping lapangan}

Kegiatan yang pertama kali dilakukan adalah pembekalan kepada mahasiswa pendamping lapangan mengenai materi pelatihan yang akan dilaksanakan di desa Pasirwaru Kec. Mancak, dalam hal ini materi yang disampaikan mengenai pengolahan limbah cangkang melinjo menjadi bahan bakar briket.

Kegiatan ini dilaksanakan di Universitas Banten Jaya, Kampus 1 Jl. Ciwaru II No. 73 Kota Serang -Banten Kegiatan oleh Ibu Tauny Akbari, S.Pd., MIL dosen Teknik Lingkungan Universitas Banten Jaya.

\section{Pelaksanaan pelatihan}

Pemberian materi mengenai proses pembuatan briket dari cangkang melinjo dan cara pemanfaatannya, pengenalan nama-nama bahan yang digunakan. Kegiatan selanjutnya yaitu pelaksanaan KKN-PPM di Desa Pasir waru kec. Mancak. 
Dalam Pembangunan Desa (Pemanfaatan Limbah Cangkang melinjo menjadi briket di Desa Pasir waru, Kec. Mancak )”. Kegiatan dilaksanakan pada hari sabtu, 29 Agustus 2019.
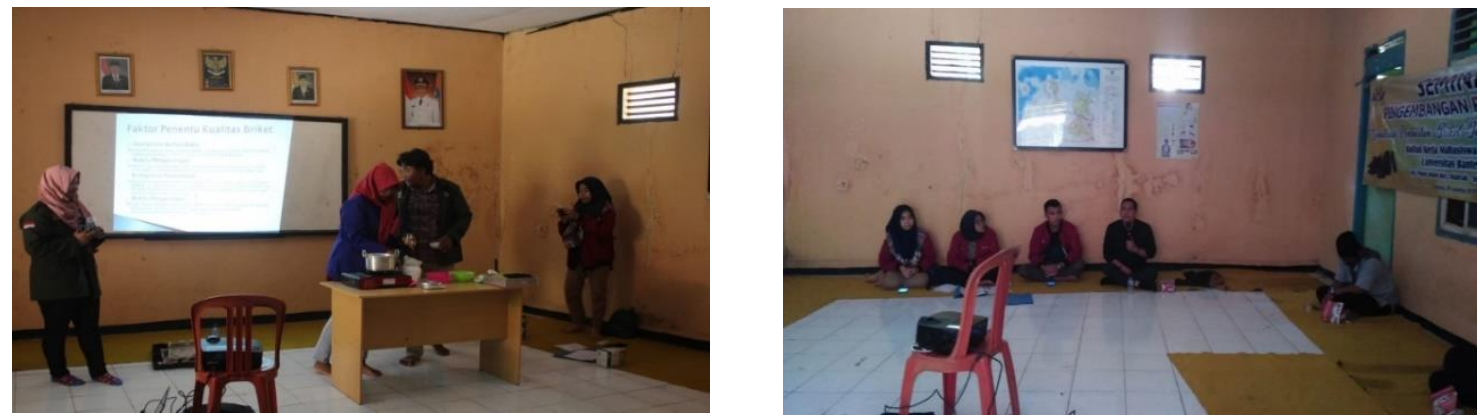

Gambar 1. Presentasi Materi Pelatihan

Kegiatan ini dilaksanakan di kantor desa Pasir waru yang dihadiri oleh sejumlah perangkat desa dan masyarakat desa dalam hal ini dikhususkan kepada pengrajin usahan melinjo sebagai pesertanya.

\section{Demonstrasi proses pembuatan Briket dari cangkang melinjo yang diperagakan oleh mahasiswa pendamping}

Kegiatan ketiga yaitu demontrasi pembuatan Briket dari cangkang melinjo. Demontrasi ini dilaksanakan oleh mahasiswa pendamping serta tim dosen pemateri KKN-PPM. Kegiatan ini diselingi tanya jawab dari masyarakat, terlebih mengenai bahan-bahan baku, baik dari nama, ukuran, harga, serta informasi serta bahan yang bisa diperoleh dari daerah setempat.
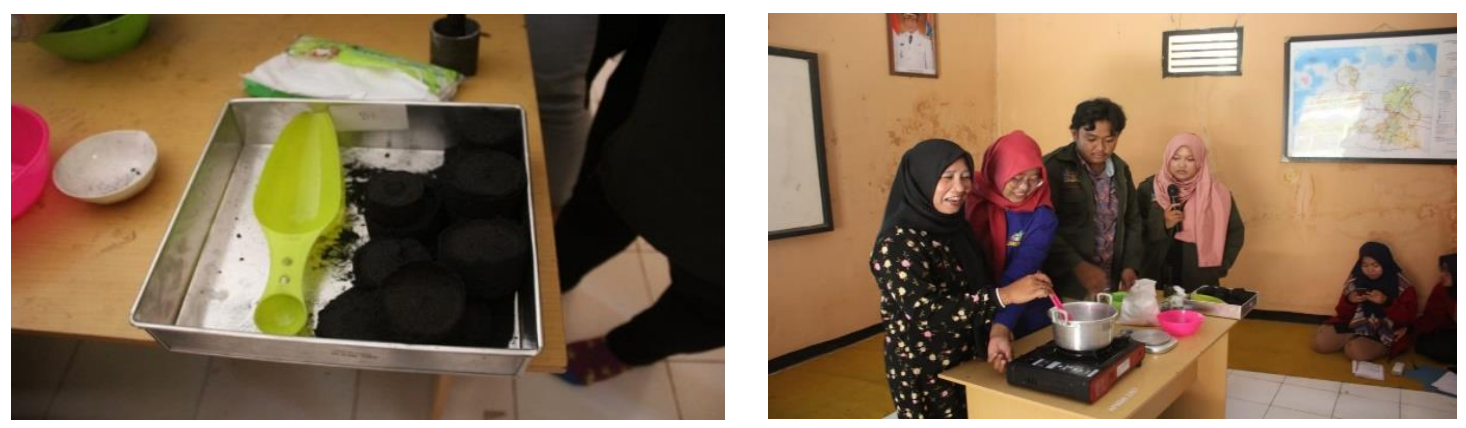

Gambar 2. Demonstrasi Pembuatan Briket dari Cangkang Melinjo

Demonstrasi ini dilakukan oleh tim mahasiswa teknik lingkungan Universitas Banten Jaya yang sudah diberikan pelatihan terlebih dahulu pada kegiatan pembekalan. Sehingga pada saat kegiatan pelaksanaan KKM, mahasiswa bisa menjadi tutor dan juga pendamping bagi masyarakat. Mahasiswa yang terlibat pada kegiatan KKM ini terdiri dari lintas fakultas dan program studi yang telah mengontrak Mata Kuliah KKM di UNBAJA. 


\section{KESIMPULAN}

Setelah dilakukan kegiatan Kuliah Kerja Mahasiswa - Tematik berbasis Problem Solving untuk memecahkan masalah dengan tema "Teknologi Tepat Guna, Kewirausahaan dan Pengembangan Budaya Banten "Program kerja dengan judul Pelatihan Pembuatan Briket tahun 2019 , upaya meningkatkan partisipasi dan keterampilan Kepada masyarakat dalam pembangunan desa (Pemanfaatan Limbah Cangkang Melinjo menjadi Briket)", Telah tersosialisasi peningkatan pengetahuan dan keterampilan masyarakat tentang mengolah Cangkang Melinjo menjadi Briket yang dapat digunakan untuk bahan bakar. Dengan meningkatkan pengetahuan dan keterampilan dalam mengolah limbah menjadi produk yang berguna dan memiliki nilai jual, harapannya masyarakat Desa Pasir warua menjadi masyarakat yang produktif.

\section{UCAPAN TERIMAKASIH}

Ucapan terimakasih disampaikan kepada ;

1. Ketua LPPM Universitas banten Jaya yang telah memberikan kesempatan dan dukungan untuk melaksanakan kegiatan Kuliah Kerja Nyata dengan tema "Teknologi Tepat Guna, Kewirausahaan dan Pengembangan Budaya Banten "Sebagai Upaya meningkatkan partisipasi dan keterampilan masyarakat dalam pembangunan desa (Pemanfaatan Limbah Cangkang Melinjo menjadi Briket) tahun pelaksanaan 2019” .

2. Kepada Ketua Pelaksana KKM-TEMATIK UNBAJA.

3. Kepada Camat Mancak Kabupaten Serang -Banten.

4. Kepala Desa Pasir Waru yang telah bekerjasama dan memberikan kesempatan untuk dapat melakukan pengabdian di desa tersebut.

5. Tim Teknik Lingkungan Universitas Banten Jaya yang telah bekerjasama dalam pelaksanaan kegiatan KKN-TEMATIK sebagai tutor dalam pembuatan Briket dari Cangkang Melinjo

\section{DAFTAR PUSTAKA}

Buku Panduan, Kuliah Kerja Mahasiswa (KKM) TEMATIK Univeritas Banten Jaya, 2019. Jurnal Studi Uji Karakteristik Fisis Briket Bioarang Sebagai Sumber Energi Alternatif. Online Jurnal of Natural Science, Vol.3(1): 89-98 ISSN: 2338-0950 March 2014.

Jurnal, Kajian Kualitas Briket Biomassa dari Sekam Padi dan Tempurung Kelapa , Jurnal Kimia VALENSI: Jurnal Penelitian dan Pengembangan Ilmu Kimia, 2 (2), November 2016, 136-142.

Jurnal, Pembuatan Briket Bioarang Dari Cangkang Dan Tandan Kosong Kelapa Sawit, Jurnal Teknologi Hasil Pertanian, Vol. VI, No.2, Agustus 2013. 